\title{
A Pécsi modellre visszapillantva 2018-ban
}

Az Iskolai Szociális Munkás Hálózat program a 2006/2007-es tanévben indult három pécsi középiskolában, majd további három közoktatási intézménnyel bővült a 2008/2009-es tanévtől: egy 8 osztályos gimnázium, egy általános iskola és egy szakiskola csatlakozott a programhoz. 2010-től 2012-ig további 6 fővárosi szakiskolában és szakközépiskolában indult el az iskolai szociálismunka-szolgáltatás. Büszkén mondhatjuk, hogy a 6 tanéven át tartó program máig az egyik legismertebb, legjobban dokumentált ilyen típusú projekt Magyarországon, amely sajátosságai miatt a hazai iskolai szociális munka területén külön modellé is vált. A programról elsősorban Az iskolai szociális munka kézikönyvében olvashatunk (Szemelyácz, Máté 2009), de szerepelt külföldi és hazai tudósításokban (International Network for School Social Work, Electronic Newsletter, School social work in Hungary - The Pécs Model, 2010; Bezdom, 2010), tevékenységeinket számtalan konferencián és szakmai fórumon is bemutathattuk. A tanulmányutak és természetesen a hosszabb-rövidebb felsőoktatási szakmai gyakorlatok a program megismerését szolgálták, de a laikus olvasó akár a Wikipédián ${ }^{1}$ is tájékozódhatott.

A modellben született szakmai segédletek egy része (forgalmi adatok rögzítését segítő tábla, munkaköri leírások, szerződések) máig ingyenesen letölthetők az Iskolai Szociális Munkások Egyesülete honlapjáról. ${ }^{2}$

A pécsi modell kialakulásának lényeges előzménye volt, hogy az INDIT Közalapítvány drogprevenciós munkacsoportja Pécsett és Baranyában megismerkedett már jól müködő iskolai szociálismunka-szolgáltatásokkal (bevált gyakorlatok megléte), sőt 2003ban a közalapítvány teamjéhez csatlakozott több iskolai szociális munkás, illetve más gyermekvédelem területén dolgozó szakember is.

Szintén jelentős szerepet játszott a program létrejöttében a 2004-ben elkészült, a pécsi iskolákban folyó gyermekvédelmi tevékenységet, illetve az iskolai szociális munka helyi lehetőségeit vizsgáló Tihanyi-Gergál-féle kutatás. Eszerint a megkérdezett pedagógusok 60\%-a szükségesnek érezte egy szociális szakember jelenlétét az iskolában, sőt nagy részük (74\%), ha tehetné, heti rendszerességgel konzultálna is vele. A vizsgálat továbbá azt is

\footnotetext{
${ }^{1}$ https://en.wikipedia.org/wiki/The_P\%C3\%A9cs_Model_of_School_Social_Work, utolsó letöltés: 2018. 08. 18. https://hu.wikipedia.org/wiki/Az_iskolai_szoci\%C3\%A1lis_munka_p\%C3\%A9csi_modellje, utolsó letöltés 2018. 08. 18.

${ }^{2}$ http://www.isme.hu/index.php?option=com_content\&view=category\&id=8\&Itemid=18, utolsó letöltés: 2018. 08.18.
} 
kimutatta, hogy a gyermek- és ifjúságvédelmi felelősök örülnének annak, ha ezt a munkakört szakmai felkészültséggel rendelkező szociális munkások töltenék be, sőt 50\%-uk a szociális szakemberek javára le is mondana e tevékenységéröl (Tihanyi 2004: 53).

A programban részt vevő iskolatípusok:

- általános iskola

- 8. osztályos általános gimnázium

- szakiskola

- szakközépiskola

- gyakorló gimnázium

A programban iskolánként alkalmaztunk egy szakembert, azaz összesen 12 föállású iskolai szociális munkást, akiknek saját konzultációs szoba is rendelkezésükre állt, és akik a fővárosban és Pécsett is 6-6 fös teamekben, ún. iskolai szociálismunkás-hálózatokban dolgoztak, ezeket egy-egy félállású koordinátor vezette. A legkisebb iskolában nagyjából 350 fö, a legnagyobban kb. 1200 fő tanult. Az iskolák egy részében a védőnő mellett iskolapszichológus is dolgozott, akikkel az adott oktatási intézményben iskolai mentálhigiénés munkacsoportot hoztak létre.

\section{A Pécsi modell sajátosságai}

- A munkáltató - mind az iskolától, mind a gyermekjóléti rendszertől - független civil szervezet (függetlenség). Előnye: a szakmai munkát nem befolyásolják terhelö alá-fölé rendeltségi viszonyok.

- Az iskolai szociális munkások hálózatban működnek, amely szakmai kontrollt és támaszt biztosít (esetmegbeszélés, egységes adminisztráció, munkanapló, forgalmi jelentés, szociális adatlap, egyéni problémakezelési tervek). Az iskolákban folyó hatékony segítő tevékenység érdekében heti rendszerességgel esetmegbeszéléseket tartanak, amelynek célja a szakmai támogatás, emellett ún. bővített, illetve nyitott esetmegbeszélőket is szerveznek havi rendszerességgel (hálózat).

- Az iskolai szociális munkások egy iskolában dolgoznak fóállásban, ott töltik munkaidejük jelentős részét, csak családlátogatás vagy esetmenedzselési, kísérési feladatok, valamint stábmegbeszélések kapcsán vannak távol. Az iskolában saját iroda áll rendelkezésükre (számítógép, közvetlen telefonálási lehetőség). Ezzel a diákok számára egyfajta, könnyen elérhető, segítséget és érzelmi támaszt nyújtó felnőtt segítő tud lenni (elérés).

- Az egységes szemlélet ugyanakkor nem zárja ki, hogy az egyes iskolákban más-más munkamódszer kapjon prioritást (például: gyakorló gimnázium - csoportmunka, müszaki szakközépiskola - közösségi munka, szakiskola - esetmunka) (rugalmasság).

- Szintén a modell jellemzője, hogy erős együttmüködéseket alakít ki az iskolai színtéren kívüli ifjúságsegítő programokkal, sőt több ilyen programot az INDIT Közalapítvány rendszerén belül müködtet: Alternatíva Ifjúsági Iroda (Magyarország első, máig müködő ún. Pláza programja), Utcai Szociális Szolgálat, BuliSegély 
Szolgálat. A különféle programok integrált müködése tulajdonképpen lehetővé teszi, hogy a szervezet akár az iskolából hosszabb-rövidebb ideig kieső, illetve ott el nem érhető fiatalok számára is képes legyen segítséget nyújtani (együttmüködés).

- Egyéni szakmai konzultáció mindegyik iskolában minimum havi rendszerességgel, amely célja a szociális munkások személyre szabott szakmai támogatása (konzultáció).

- A szociális munkások a befogadó iskolában igyekeznek egy egészségfejlesztési munkaközösség (iskolai védőnő, iskolaorvos, iskolapszichológus, rendezvényszervező, ifjúságvédelmi felelős, osztályfőnök stb.) tagjaként is dolgozni, illetve ilyen teameket facilitálni (csapat).

- A program lebonyolítása során kiemelt szerepet kap a hatékonyságmérésre való törekvés (adminisztráció, nyilvánosság) (hatékonyság).

- Programszemléleti kerete: gyermekekre orientálódó iskolai szociális munka, illetve a modern ökológiai modellekből építkezik. Az iskolai szociális munkás saját módszerein keresztül - esetmunka, szociáliscsoport-munka, közösségi munka - próbál meg preventív jelleggel a gyermekek problémáira megoldást találni. Az iskolai szociális munka önálló intézmény, autonóm módon cselekszik, nincs az iskolavezetésnek alárendelve, független fenntartó finanszírozza, ugyanakkor szupervíziós és esetmegbeszélő teamek segítségére támaszkodhat. A gyermekkel, a családdal és az iskolával egyaránt kapcsolatban áll, az egészre koncentrál, egyszerre veszi tekintetbe a környezet és a személyiség komplexitását. Az iskolai szociális munkás tevékenysége során a kliensei erősségére koncentrál, a védőtényezők megerősítésére törekszik, ugyanakkor számol a problémák komplexitásával, és az azok kezelésére hivatott szakmák sokszínűségével. A megoldásokat multidiszciplináris team segítségével keresi (tudományosság) (Gergál, Máté 2009: 96-97).

A korábban létrejött Pécsi Iskolai Szociális Munkás Hálózat tapasztalatait képzésekkel, pécsi „intézménylátogatással” adtuk tovább a 2010-ben induló budapesti program munkatársainak. Az indulás után is volt folyamatos konzultációs lehetőség főként telefonon, de időközönként személyesen is.

Azonkívül, hogy a pécsi hálózatnak nem volt „intézményesült” előzménye, a két program indulásában fellelhető egy jelentős különbség, amely esetleg a napjainkban elindult óvodai-iskolai szociális segítő programok számára tanulságos lehet:

Pécsett még a pályázat megkezdése előtt partneriskolákat kerestünk. Összesen 10 közoktatási intézmény vezetését kerestük fel és elmondtuk, hogy egy föállású iskolai szociális munkást szeretnénk foglalkoztatni, aki az adott iskolában dolgozna. Az iskolákkal elöre megismertettük a munka főbb tartalmát (szolgáltatási palettát), és a munka beindításához egy külön konzultációs szobát kértünk, amelynek esetleges felújítási és berendezési költségét magunkra vállaltuk. Valamennyi iskolának hagytunk időt a jövendőbeli partnerség átgondolására. Végül - nagy örömünkre - mindegyik megkeresett iskola együttmüködési szándékát nyilvánította ki, így 10 iskolából választhattuk ki azt a hármat, ahol 2006 őszén megkezdtük a programot. 
Ezzel szemben Budapesten a fővárosi önkormányzat illetékes szakbizottsága jelölte ki a leendő partnerintézményeket, emiatt az iskolák egy része nem lehetőségnek, hanem sokkal inkább kényszernek élte meg a pályázatot. Ez a későbbi gyakorlati munkára is negatív hatású volt. Bár mindent megtettünk azért, hogy a „kényszerü együttmüködés” stigmáját lemossuk a programról, néhány iskolában ez nem sikerült. Ezekben az iskolákban a vezetés vagy annak egy része mindvégig bizalmatlan és ellenálló volt a programmal szemben. Olyannyira, hogy a hatból egy helyen csak az iskola igazgatójának nyugdíjazása után bekövetkezett új szemlélet, egy másik helyen pedig új partneriskola keresése hozott változást. Tapasztalataink szerint az iskola vezetése a program kivitelezésére nézve meghatározó: ha bizalmatlan, illetve erővel, akarata ellenére ráerőltetettnek éli meg a „közös pályázatot”, akkor az a program lebonyolítását lényegében ellehetetlenítheti. Egy szolgáltatás elfogadtatása különösen sok energiabefektetést igényel egy olyan szakterület esetében, amely a társadalom nagy része számára szinte teljesen ismeretlen. Tapasztalatunk szerint a program úgynevezett beérése, azazhogy az iskola valamennyi polgára (felnőttek, diákok, szülők, pedagógusok, kisegítő személyzet) számára érthetővé váljék, hogy az iskolai szociális munkás miben tud segíteni, hol vannak a kompetenciahatárai stb., akár két tanév is lehet. Ezért javasoltuk az illetékeseknek, hogy kezdetben kisebb volumenü és mindenképpen partneri, önkéntes együttmüködésen alapuló iskolai szociálismunkás-hálózatok induljanak, hiszen ezeknek nagyobb esélyük van a programok optimális lebonyolítására, melyek sikerességük miatt, növelhetik az iskolai szociális munka ismertségét, illetve presztízsét.

A Pécsi modell végül az egyre apadó pályázati források miatt 2012-ben megszünt. Volt olyan „tehetősebb” iskola, ahol a köznevelési intézmény tovább foglalkoztatta az iskolai szociális munkást. Mindezek arra utalnak, hogy a külön címkézett támogatások (akár iskoláknak közvetlenül), pályázati források, illetve úgynevezett kvázi normatív finanszírozási megoldások szinte mindenképpen szükségesek a programok fennmaradásához. Ez utóbbi azt jelenti, hogy ha hosszabb távra, 3-5 évre szól a pályázat elnyerése, ez idő alatt a nyertes/befogadott pályázatok lényegében normatív támogatásként számíthatnak a forrásokra. (Ilyen volt korábban a támogató szolgálatok rendszere is.)

Napjainkban az iskolai szociális munka pécsi modelljében dolgozó szakemberekből ketten még mindig iskolai szociális munkásként dolgoznak, mindketten az úgynevezett belső modell szerint. Ök és még közülük néhányan az iskolai szociális munka területén belül módszertani és szakmai, tartalmi kérdésekkel is foglalkoznak, elsősorban iskolai színterü prevenciós programok fejlesztésében és megvalósításában vesznek részt:

- MIND-projekt kortárs bántalmazás és iskolai erőszak megelőzésére irányuló program. $^{3}$

\footnotetext{
${ }^{3}$ http://www.kormanyhivatal.hu/download/5/0a/c3000/MIND-PROJEKT.pdf, letöltés: 2018. 08. 18.
} 
- FÜGE komplex egészségfejlesztési szemléletű devianciaprevenciós program (drogprevenciós foglalkozás). ${ }^{4}$

- CSAT-projekt - párkapcsolati eröszak prevencióját megcélzó középiskolásoknak szóló program. ${ }^{5}$

- Alter Kortárs Mühely - kortárssegítő program. ${ }^{6}$

\section{Irodalomjegyzék}

BEZDOM I. (2010): Budapestre ér a pécsi szál. Köznevelés, 11. szám. 14-16.

GERGÁL T., MÁTÉ ZS. (2009): Az iskolai szociális munka lehetőségei: a pécsi modell. In MÁTÉ ZS., SZEMELYÁCZ J. (szerk.): Az iskolai szociális munka kézikönyve. INDIT Közalapítvány, Pécs. 81-98.

MÁTÉ ZS., SZEMELYÁCZ J. (szerk.) (2009): Az iskolai szociális munka kézikönyve. INDIT Közalapítvány, Pécs.

School social work in Hungary - The Pécs Model. In International Network for School Social Work, Electronic Newsletter. January, 2010.

TIHANYI T. (2004): Új feladatok - új szerepek - új státuszok az iskolai gyermekvédelemben. Szakdolgozat. Pécs.

\section{Internetes hivatkozások:}

https://en.wikipedia.org/wiki/The_P\%C3\%A9cs_Model_of_School_Social_Work (utolsó letöltés: 2018. 08. 18.).

https://hu.wikipedia.org/wiki/Az_iskolai_szoci\%C3\%A1lis_munka_p\%C3\%A9csi_modellje (utolsó letöltés: 2018. 08. 18.).

http://www.indit.hu/wp-content/uploads/2018/01/alternativa-kortarssegito-program_web.pd (letöltés: 2018. 08. 18.).

http://www.isme.hu/index.php?option=com_content\&view=category\&id=8\&Itemid=18 (utolsó letöltés: 2018. 08. 18.).

\footnotetext{
${ }^{4}$ http://www.egeszseg.hu/szakmai_oldalak/assets/cikkek/16-11/programdokumentacio.pdf, letöltés: 2018. 08. 18.

${ }^{5}$ http://www.kormanyhivatal.hu/download/4/0a/c3000/CSAT-PROJEKT.pdf, letöltés: 2018. 08. 18.

${ }^{6}$ http://www.indit.hu/wp-content/uploads/2018/01/alternativa-kortarssegito-program web.pd, letöltés: 2018. 08. 18.
} 
DOI: $10.29376 /$ parbeszed/2018/3/6

http://www.kormanyhivatal.hu/download/4/0a/c3000/CSAT-PROJEKT.pdf (letöltés: 2018. 08. 18.).

http://www.kormanyhivatal.hu/download/5/0a/c3000/MIND-PROJEKT.pdf (letöltés: 2018. 08. 18.). 